\title{
Первые данные о синаккреционном умереннобарическом метаморфизме на западной окраине Сибирского кратона (Енисейский кряж)
}

\author{
(С2020 П. С. Козлов ${ }^{1}$, И. И. Лиханов ${ }^{2 凶}$, В. В. Хиллер ${ }^{1}$ \\ ${ }^{1}$ Институт геологии и геохимии им А. Н. Заварицкого, Уральского отделения Российской \\ академии наук, ул. Вонсовского, 15, 620016, Екатеринбург, Российская Федерация \\ ${ }^{2}$ Институт геологии и минералогии им. В. С. Соболева Сибирского отделения Российской \\ академии наук, пр. акад. Коптюга, 3, 630090, Новосибирск, Российская Федерация
}

\begin{abstract}
Аннотация
Введение: Тектоническая эволюция окраин Сибирского кратона имеет важное значение для глобальных палеогеографических реконструкций, особенно в отношении сложной геологической истории Центральной Азии. Енисейский кряж, представляющий собой древний покровно-складчатый ороген на западной границе Сибирского кратона, является частью Центрально-Азиатского орогенного пояса (ЦАСП) и ключевой структурой для понимания докембрийской тектонической эволюции Сибирского кратона и роста земной коры в ЦАСП. Аккреционно-коллизионные процессы в неопротерозойской истории этого региона генетически и пространственно связаны со становлением Палеоазиатского океана (ПАО). Проблемы связи террейнов Енисейского кряжа с развитием ПАО и их последующей аккреции к Сибирскому кратону во многом еще далеки от окончательного решения, что повышает интерес к особенностям развития аккреционно-субдукционных структур в зонах перехода палеоокеан-континент. В статье обсуждаются вопросы генетической связи тектоники и метаморфизма с аккреционно-коллизионными процессами на конвергентной границе плит на западной окраине Сибирского кратона.

Методика: Выполнено петролого-геохимическое и геохронологическое изучение гранат-ставролит-кианитовых бластомилонитов гаревского метаморфического комплекса Енисейского кряжа.

Результаты и обсуждение: На ранней стадии (630-610 млн лет) сформировались метакомплексы близкие по составу к парным метаморфическим поясам, характеризующиеся сопряженным проявлением глаукофансланцевого HP/LT метаморфизма (8-10 кбар/400-450 $\left.{ }^{\circ} \mathrm{C}\right)$ и зонального LP/HT метаморфизма низких давлений андалузит-силлиманитового типа (3.4-3.6 кбар $\left./ 435-450^{\circ} \mathrm{C}\right)$. В ходе последующих (610-590 млн лет) аккреционно-коллизионных деформационных процессов они испытали динамометаморфизм при (6.3-6.6 кбар/570-600 $\mathrm{C})$ с образованием более высокобарических тектонитов шовной зоны.

Заключение: Установлено полициклическое развитие процессов формирования этих пород на конвергентной границе «палеоконтинент-палеоокеан» в интервале времени 630-590 млн лет.

Ключевые слова: метаморфизм, геотермобарометрия, in situ U-Th-Pb геохронология по монацитам, гаревский комплекс, Сибирский кратон.

Источник финансирования: Работа выполнена по плану научно-исследовательских работ ИГМ СО РАН им. В.С. Соболева (Новосибирск) и по проекту РФФИ (№ 18-05-00152), и в рамках госзадания ИГГ УрО РАН (Екатеринбург; АААА-А18-118052590032-6).

Для цитирования: Козлов П. С., Лиханов И. И., Хиллер В. В. Первые данные о синаккреционном умереннобарическом метаморфизме на западной окраине Сибирского кратона (Енисейский кряж) // Вестник Воронеж. гос. ун-та. Сер. Геология. 2020. №1. С. 78-86. DOI: https://doi.org/10.17308/ geology.2020.1/2516
\end{abstract}

Контент доступен под лицензией Creative Commons Attribution 4.0 License.

\footnotetext{
Лиханов Игорь Иванович, E-mail: likh@igm.nsc.ru
} 


\section{Введение}

Взаимоотношение океанической и континентальной литосферы на конвергентных границах плит одна из актуальных проблем для расшифровки истории геологического развития складчатого обрамления краевых частей кратонов [1]. Граница палеоокеанпалеоконтинент и зона их сочленения в глобальном масштабе важны для понимания истории ранних этапов эволюции Палеоазиатского океана [2-4].

Енисейский кряж - уникальный ороген, образовавшийся в результате вендского аккреционно-коллизионного события с причленением Исаковского и Предивинского террейнов к западной окраине Сибирского кратона [5]. Аккреционные комплексы на границе палеоокеан-палеоконтинент представлены контрастными по составу породами континентальной и океанической коры [6]. Здесь в пределах сутурной зоны были обнаружены реликты пород с глаукофаном, сформированные 630-610 млн лет назад при $P-T$ условиях метаморфизма 8-10 кбар $/ 400-450^{\circ} \mathrm{C}$ и высокобарических апобазитовых тектонитов с возрастом 600 млн лет при 11-15 кбар/550-640 [7]. Эти наблюдения позволили сделать заключение о вероятном проявлении на западе Сибирского кратона конвергентной границы “чилийского" типа, контролируемой процессами палеосубдукции океанической коры под континентальную окраину [8, 9].

Статья решает одну из проблем реконструкции тектоно-метаморфических событий на конвергентной границе плит в неопротерозое. Её цель - показать генетическую связь тектоники и метаморфизма с аккреционно-коллизионными процессами и синхронность метаморфизма при формировании высокобарических метабазитов в сутурной зоне и умереннобарических апогнейсовых бластомилонитов в гаревском метакомплексе. Выполненные нами петролого-геохимические и геохронологические исследования позволили выяснить их возраст и $P-T$ условия образования тектонитов, свидетельствующие о полициклическом характере тектоно-метаморфических событий в регионе.

\section{Объект исследования}

В качестве объекта исследования выбран гаревский метаморфический комплекс (ГМК) западной окраины Сибирского кратона, сложенный древнейшими в Заангарье Енисейского кряжа полиметаморфическими кристаллическими породами неоархея?палеопротерозоя $[10,11]$. Он располагается в восточной части Приенисейской региональной сдвиговой зоны (ПРСЗ) - крупной деформационно-метаморфической линеаментной структуры региона, протягивающейся вдоль западной окраины кряжа не менее чем на 200 км при ширине - до первых десятков километров [12]. Она представляет собой систему субпараллельных разломов сдвиговой, взбросовой и надвиговой кинематики, концентрирующих деформации сдвига, а также их комбинаций с проявлениями приразломного катаклаза, меланжирования и динамоме- таморфизма породных массивов [13]. Эти зоны играют роль швов, разделяющих кратонные блоки от Исаковского и Предивинского островодужных террейнов на северо-западе Саяно-Енисейского аккреционного пояса, и являются областями их активного взаимодействия. Интерпретация геохронологических данных разновозрастных популяций монацитов в тектонитах, испытавших перекристаллизацию в ходе последовательных деформационных процессов, указывает на неоднократную активизацию ПРСЗ в регионе в значительном диапазоне времени 1.54-0.6 млрд лет [14].

В строении ГМК принимают участие биотитовые плагиогнейсы немтихинской толщи, которые выше по разрезу сменяются порфиробластическими плагиогнейсами и гранат-двуслюдяными кристаллическими сланцами с подчиненным количеством амфиболитов и метатерригенно-карбонатных пород (кварцитов, кальцифиров, мраморов) малогаревской толщи с широким развитием в них пегматитов, апорапакивигранитных бластомилонитов, продуктов ультраметаморфизма (мигматитов) [15]. В районе исследования эти породы испытали три этапа метаморфизма, различающихся термодинамическими режимами и величинами метаморфических градиентов [16]. На первом этапе в начале неопротерозоя ( 1.1 млрд. лет) в связи с гренвильской орогенией сформировались зональные метаморфические комплексы низких давлений андалузит-силлиманитового типа при типичном для орогенеза метаморфическом градиенте $d T / d H=20-30^{\circ} \mathrm{C} /$ км. На втором этапе эти породы подверглись позднерифейскому (801-793 млн лет) коллизионному метаморфизму умеренных давлений кианит-силлиманитового типа с низким $d T / d H \leq 10^{\circ} \mathrm{C} /$ км. Заключительный этап сопровождался синэксгумационным метаморфизмом (785-776 млн лет) с $d T / d H \leq 12^{\circ} \mathrm{C} /$ км, отражающим тектонические обстановки быстрого подъема породных блоков в сдвиговых зонах [17].

\section{Петрография и геохимия пород}

В составе этого комплекса были изучены участки малогаревской толщи в 1.5 км выше устья в правобережьи р. Гаревка, представленные мраморами и залегающими выше ставролит-кианит-гранатовыми линзовидно-полосчатыми гнейсами (рис. 1а) с развитием порфиробластов граната с содержанием 3-5 об\%, в отдельных полосках - до 30 об\%. По химическому coставу (мас\%) гнейсы классифицируются как низкокальциевые (0.48) и низконатровые (0.25), умеренно насыщенные калием (3.6) метапелиты, одновременно обогащенные железом (до 12) и глиноземом (до 20). Их отличительной особенностью по сравнению с другими высокоглиноземистыми метапелитами [18-20] является отсутствие плагиоклаза и развитие кианита в матриксе (рис. 1b), что указывает на особенности его возникновения в специфических условиях. Во всех других случаях кианит появлялся при полиморфном замещении реликтового андалузита в крупных псевдоморфозах. 

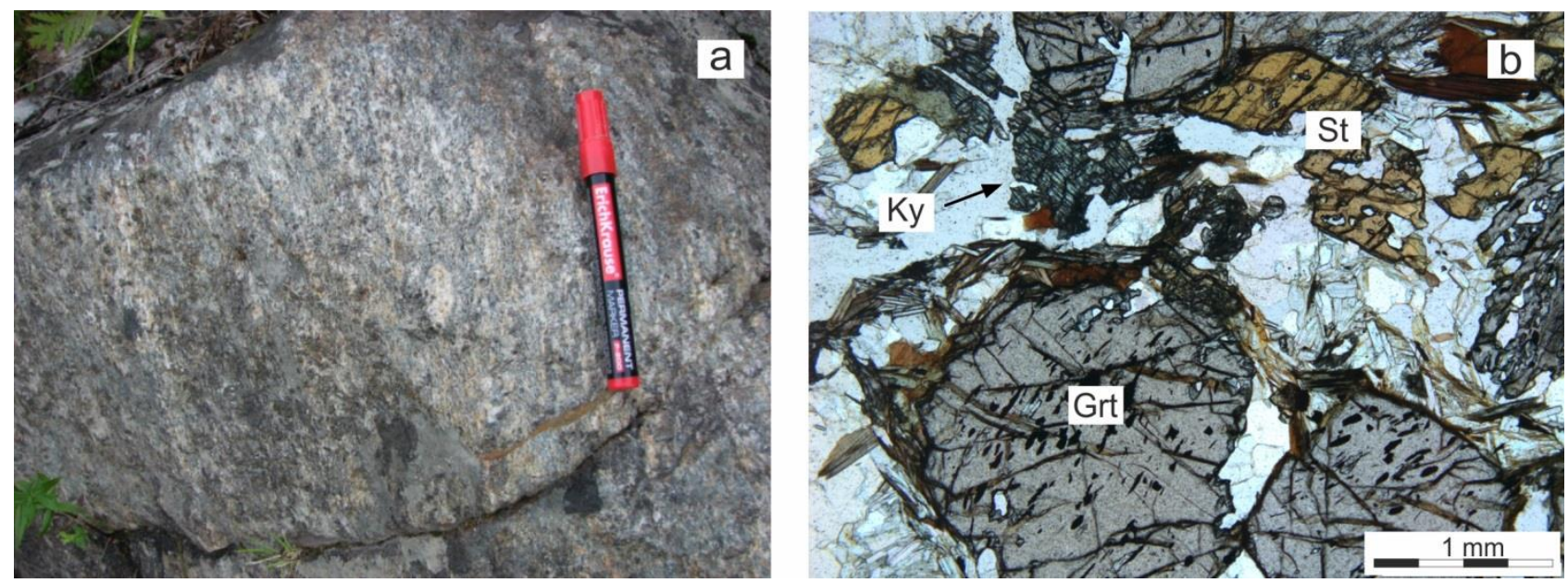

Рис. 1. Обнажение гранат-ставролит-кианитовых гнейсов малогаревской толщи палеопротерозоя (а) и микрофотография петрографического шлифа, иллюстрирующая присутствие кианита и ставролита в межзерновом пространстве порфиробласт граната со следами вращения (шлиф № 13-12, николи параллельны) (b).

[Fig. 1. Field photos rock outcrop of garnet-staurolite-kyanite gneisses of the Malaya Garevka Group (a), and photomicrographs of thin section showing the presence of kyanite and staurolite in the intergranular space of garnet porphyroblast with traces of rotation (sample number 13-12, parallel nicols) (b)].

Другими основными породообразующими минералами этих пород являются ставролит, биотит, мусковит и хлорит. Зерна граната (размером до 5-7 мм) имеют три зоны - внутреннюю, среднюю и внешнюю. Ядра представлены розовым гранатом, средняя и внешняя зоны сложены гранатом с обилием черных пластинчатых микровключений ильменита и графита, ориентированных под углом 75-80 к рассланцеванию. Монацит встречается в средней и внешней зонах граната и в матриксе породы.

Микроэлементный состав высокоглинозёмистых кианитовых гнейсов характеризуется близкими значениями редкоземельных и радиоактивных элементов в сравнении с кианитсодержащими метапелитами умеренных давлений коллизионного метаморфизма Заангарья [21-23]. Незначительные повышения в концентрациях Y, Gd, Tb, Er и других тяжелых Р3Э могут быть связаны с близостью гнейсов к шовной зоне ПРСЗ.

\section{Химизм минералов и Р-Т условия метаморфизма}

Химический состав минеральных фаз гнейсов установлен с помощью ренгеноспектрального микроанализатора Jeol JХA-8100 в ИГМ СО РАН (Новосибирск). Во внутренней зоне компонентный состав граната от центра к краю ядра меняется незначительно - $\mathrm{Alm}_{84-85}, \operatorname{Prp}_{6-7}, \mathrm{Grs}_{6-7}, \mathrm{Sps}_{1-2}$. В средней зоне происходит уменьшение альмандинового компонента до $\mathrm{Alm}_{80-81}$ синхронно с ростом содержания пиропового минала до $\operatorname{Prp}_{14-15}$ с существенным понижением железистости $\left(\mathrm{X}_{\mathrm{Fe}}\right)$ от $\mathrm{X}_{\mathrm{Fe}}=0.92-0.93$ в ядре до $\mathrm{X}_{\mathrm{Fe}}=0.85$ 0.84 в средней зоне. Характерной особенностью минералов-силикатов этих пород является высокая железистость. Железистость ставролита варьирует в узком диапазоне 0.82-0.84. Биотит незонален, его химический состав отличается малыми вариациями железистости $\left(\mathrm{X}_{\mathrm{Fe}}=0.48-0.50\right)$. Для мусковитов харак- терны слабые вариации содержания селадонитового компонента $\left((\mathrm{Mg}+\mathrm{Fe}) /\left(\mathrm{Mg}+\mathrm{Fe}+\mathrm{Al}^{\mathrm{VI}}\right)=0.05-0.10\right)$ и несколько более значительные изменения железистости $\left(\mathrm{X}_{\mathrm{Fe}}=0.5-0.67\right)$. Хлорит химически однороден во всех образцах с постоянной железистостью $\mathrm{X}_{\mathrm{Fe}}=0.48$. Состав кианита из кристаллических сланцев близок к его стехиометрической формуле с незначительными различиями в содержаниях $\mathrm{Al}_{2} \mathrm{O}_{3}$ и $\mathrm{FeO}$.

$P-T$ параметры метаморфизма пород рассчитаны на основе реальных составов породообразующих минералов и их зональности с помощью стандартных минеральных геотермобарометров - при совместном использовании калибровок и соответствующих моделей состав-активность для Grt-Bt геотермометра [24] и Grt-Bt-Ms-Als-Qz геобарометра [25] в пакете MATHEMATICA 5.0 с помощью стандартных процедур [26].

Выполненные расчеты показали, что $P-T$ условия метаморфизма пород, вычисленные в разных генерациях граната, имеют существенные различия, тогда как одноименные зоны гранатов сформировались при схожих параметрах в пределах точности измерений. Средние оценки $P-T$ условий варьируют в следующих интервалах: для внутренних генераций граната 3.43.6 кбар $/ 440-450^{\circ} \mathrm{C}$, для средних 6.3-6.6 кбар/570$600^{\circ} \mathrm{C}$. Ошибки определения $P$ - $T$ параметров, вычисленные с учетом аналитических погрешностей и энтальпии реакций, не превышают $\pm 30^{\circ} \mathrm{C}$ и \pm 0.5 кбар [27], что согласуется с цитируемыми в литературе неопределенностями геотермобарометров [28].

$P-T$ тренды эволюции метапелитов имеют весьма схожую конфигурацию, в строении которой отчетливо выделяются два этапа, различающиеся термодинамическими режимами и величинами метаморфических градиентов. На первом этапе, контролируемом зональностью во внутренней зоне граната, сформировались породы в условиях эпидот- 
амфиболитовой фации регионального метаморфизма низких давлений $\left(3.36\right.$ кбар $/ 437^{\circ} \mathrm{C}$ и 3.55 кбар $\left./ 450^{\circ} \mathrm{C}\right)$, что соответствует погружению блока пород в среднюю часть континентальной коры при характерном для орогенных поясов метаморфическом градиенте $d T / d H \sim 20-30^{\circ} \mathrm{C} /$ км [29]. На втором этапе эти породы подверглись метаморфизму умеренных давлений с образованием парагенезиса $G r t+K y+S t+B t+M s+C h l+$ $I l m+M n z$ при повышении давления от 3.4-3.6 до 6.36.6 кбар при незначительном росте температуры $\left(450-600^{\circ} \mathrm{C}\right)$, что указывает на низкую величину градиента с $d T / d H \leq 14^{\circ} \mathrm{C} /$ км.

\section{Геохронология}

Датирование метапелитов производилось по зернам метаморфогенного монацита в шлифах in situ изохронным химическим методом CHIME на основании содержания $\mathrm{Th}, \mathrm{U}$ и $\mathrm{Pb}$, определенных на электронно-зондовом микроанализаторе Сатеса SX 100 (ИГГ УрО РАН, Екатеринбург). Исследование зерен монацита из пробы 13-12 (рис. 2) проведены при ускоряющем напряжении 15 кВ, силе тока 250 нА. В среднем, пределы обнаружения $\mathrm{Th}, \mathrm{U}$ и $\mathrm{Pb}$ составили около 350, 530 и 94 ppm, соответственно. По данным микрозондового анализа монациты относятся к цериевой разновидности с высоким содержанием (мас\%) тория (1.7-8.0), урана (0.36-0.68), свинца (0.08-0.24), иттрия (до 1.15) и кальция (0.43-0.58).

Рассчитаны возраста монацита исходя из единичных определений (53 точек) содержания $\mathrm{Th}, \mathrm{U}, \mathrm{Pb}$, что составило $596 \pm 16$ млн лет $($ СКВО $=0.05)$ (рис. 3a). Также по углу наклона прямой (изохронны на графике $\left.\mathrm{ThO}_{2}{ }^{*}-\mathrm{PbO}\right)$ определен возраст и погрешность $587 \pm 18$ млн лет $(\mathrm{CKBO}=0.59)$ (рис. 3б). Ошибка при определении возраста данным методом составила менее 3 отн $\%$, что зачастую сопоставимо с изотопными значениями. Эти датировки представляют оценку абсолютного возраста позднего этапа умереннобарического коллизионного метаморфизма в ГМК, которые с учетом неточностей метода согласуются с аргон-аргоновыми определениями возрастов тектонитов (595-608 млн лет) по мусковиту и биотиту $[7,14]$.

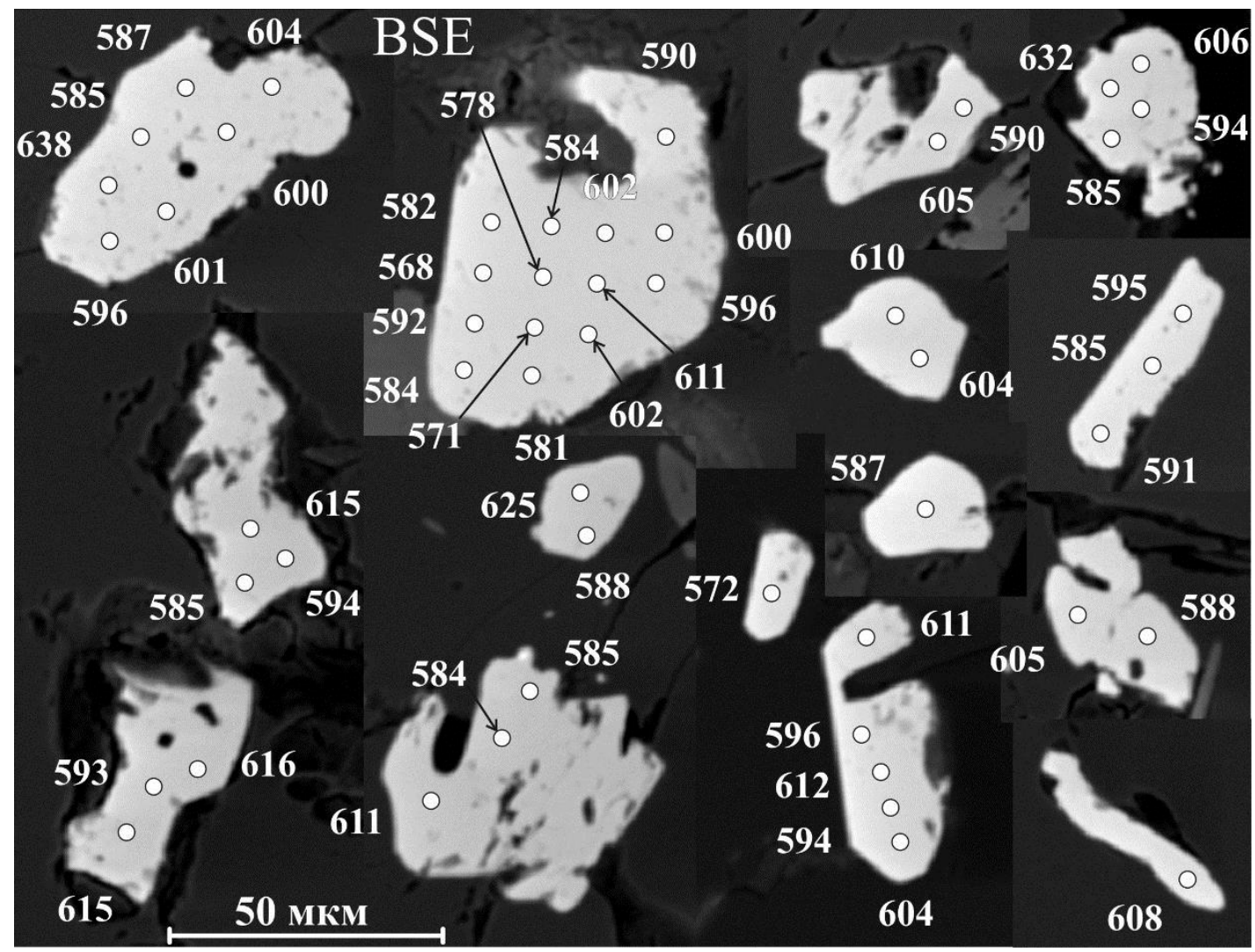

Рис. 2. Изображение зёрен монацита в обратно-рассеянных электронах с указанием точек анализа и возраста.

[Fig. 2. Back scattered electron (BSE) images of monazite grains with location of analytical spots (circles) and the Calculated concordant ages].

\section{Обсуждение результатов и выводы}

Ядра гранатов изученных гнейсов отвечают андалузит-силлиманитовому типу метаморфизма низких давлений. Если предположить, что время их формирования близко к возрасту образования глаукофановых ассоциаций в зоне палеосубдукции (630-610 млн лет), то зону аккреционно-коллизионного сочленения Исаковского террейна с окраиной Сибирского кратона можно условно трактовать как парный метаморфический пояс. Согласно А. Миясиро [30], субдукция порождает такие сопряженные области, охватывающие проявления метаморфизма высоких давлений-низких температур 

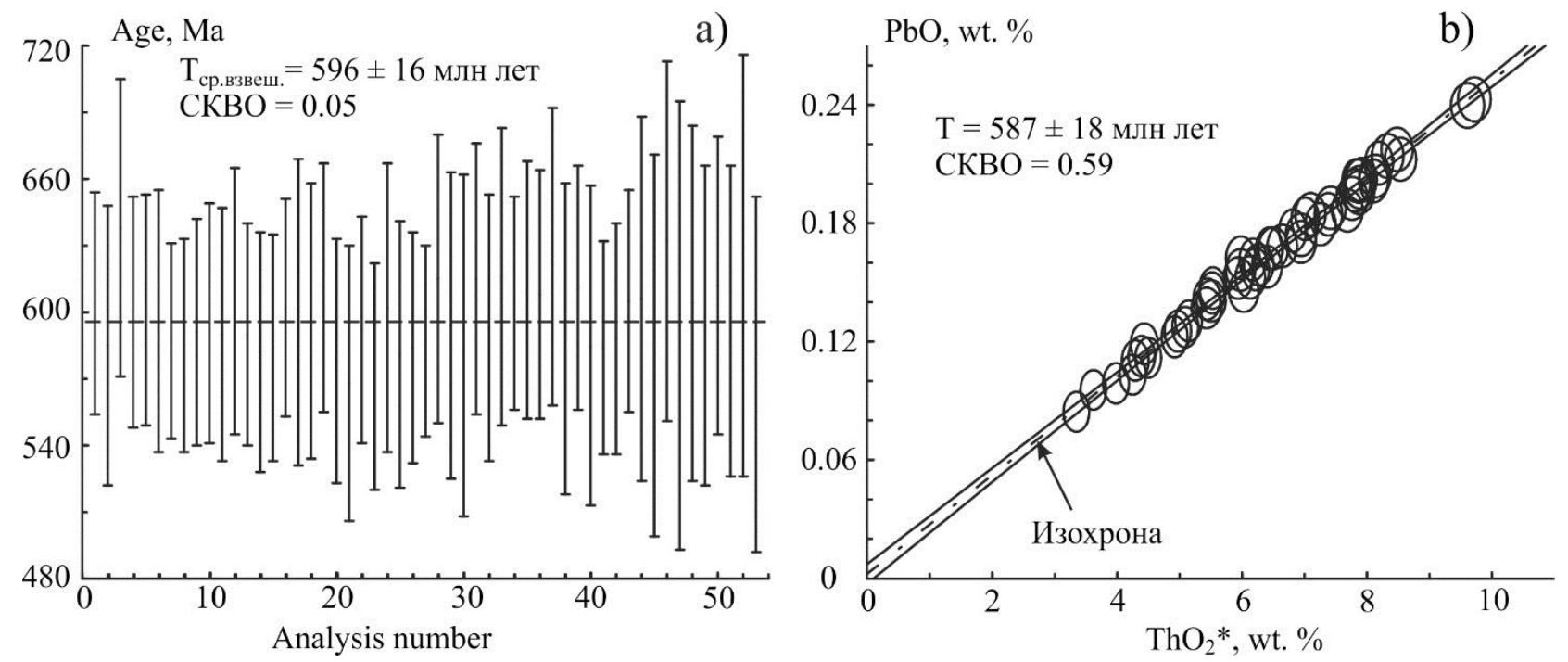

Рис. 3. Вариации значений Th-U-Pb - возрастов и их средневзвешенная величина для 53-х точечных определений (a) и изохрона по $\mathrm{ThO}_{2} / \mathrm{PbO}$ данным для монацита из гранат-ставролит-кианитового гнейса (b).

[Fig. 3. Th- $-\mathrm{U}-\mathrm{Pb}$ weighted mean ages for 53 single data points in monazite (a) and concordia age for population of data on $\mathrm{PbO} / \mathrm{ThO}_{2} *\left(\mathrm{ThO}_{2}\right.$ plus the equivalent of $\left.\left.\mathrm{UO}_{2}\right)(\mathrm{b})\right]$.

вблизи глубоководного желоба и метаморфизма низких и умеренных давлений-высоких температур на удалении от желоба под вулканическим поясом. Каймы граната сформировались позднее (около 587 млн лет назад) при $P-T$ условиях 6.6-6.8 кбар $/ 570-600^{\circ} \mathrm{C}$, что способствовало формированию ассоциаций с участием кианита. В целом, эти $P-T$ параметры несколько ниже данных по другим гнейсам ГМК (разрезы рек Енисей, Тис, Гаревка), подвергнутым более древнему коллизионному метаморфизму с возрастом около 800 млн лет [16]. В Заангарье Енисейского кряжа они сопоставимы с породами внутренних зон кианит-силлиманитового метаморфизма тейского комплекса [10-12], но отличаются от них более низким $d T / d P$ градиентом. Предполагается, что это мог быть менее погруженный блок региональнометаморфизованных пород андалузит-силлиманитовой фациальной серии, попавший в ПРС3 с последующим формированием маломощных зон кианитовых бластомилонитов.

Таким образом, нами установлено полициклическое развитие контрастных пород позднего неопротерозоя в узком интервале времени 630-590 млн лет с двумя пиками. На ранней стадии их эволюции (630610 млн лет) сформировались метакомплексы, близкие к парным метаморфическим поясам. Они характеризуются проявлением глаукофансодержащих высокобарических ассоциаций, принадлежащих метаостроводужным и метаофиолитовым комплексам, и низкобарических комплексов андалузит-силлиманитового типа континентальной окраины Сибирского кратона. В ходе последующих аккреционно-коллизионных поддвиго-сдвиговых процессов (610-590 млн лет назад) они испытали динамометаморфизм с образованием высокобарических и умереннобарических парагенезисов кианит-силлиманитового типа в пределах ПРСЗ, что свидетельствует о высокой эндоген- ной активности на конвергентной границе палеоокеанической и палеоконтинетальной плит.

Конфликт интересов: Авторы декларируют отсутствие явных и потенциальных конфликтов интересов, связанных с публикацией настоящей статьи.

\section{ЛИТЕРАТУРА}

1. Ревердатто В. В., Лиханов И. И., Полянский О. П., Шеплев В. С., Колобов В. Ю. Природа и модели метаморфизма. Новосибирск: Изд-во СО PAH, 2017. 331 с. URL: https://elibrary.ru/item.asp?id=29167743 (дата обращения: 04.02.2020)

2. Добрецов Н. Л. Эволюция структур Урала, Казахстана, Тянь-Шаня и Алтае-Саянской области в УралоМонгольском складчатом поясе (Палеоазиатский океан) // Геология и геофизика. 2003. Т. 44. № 1-2. С. 5-27. URL: http://sibran.ru/en/journals/ID=120367\&ARTICLE_ID=122168 (дата обращения: 04.02.2020).

3. Лиханов И. И., Ножкин А. Д., Савко К. А. Аккреционная тектоника комплексов западной окраины Сибирского кратона // Геотектоника. 2018. Т. 52. № 1. С. 28-51. DOI: $10.7868 / \mathrm{S} 0016853 \times 18010022$

4. Козлов П. С., Филиппов Ю. Ф., Лиханов И. И., Ножкин А. Д. Геодинамическая модель эволюции Приенисейской палеосубдукционной зоны в неопротерозое (западная окраина Сибирского кратона), Россия // Геотектоника. 2020. T.54. № 1. C. 62-78. DOI: 10.1134/S0016853X20010063

5. Лиханов И. И., Ножкин А. Д., Ревердатто В. В., Козлов П. С. Гренвильские тектонические события и эволюция Енисейского кряжа, западная окраина Сибирского кратона // Геотектоника. 2014. Т. 22. № 5. С. 32-53. DOI: $10.7868 / \mathrm{S} 0016853 X 1405004 X$

6. Лиханов И. И., Савко К. А. Первые данные о природе и возрасте протолита высокобарических тектонитов Енисейского кряжа: связь с ранним этапом формирования палеоазиатского океана // Доклады Академии Наук. 2019. Т. 484. № 6. C. 739-744. DOI: 10.31857/S0869-56524846739-744

7. Likhanov I. I., Régnier J.-L., Santosh M. Blueschist facies fault tectonites from the western margin of the Siberian Craton: Implications for subduction and exhumation associated with 
early stages of the Paleo-Asian Ocean // Lithos. 2018. Vol. 304307. pp. 468-488. DOI: 10.1016/J.LITHOS.2018.02.021

8. Лиханов И. И., Козлов П. С., Савко К. А., Зиновьев С. В., Крылов А. А. Первые петрологические свидетельства субдукции на западной окраине Сибирского кратона // Доклады Академии Наук. 2019. Т. 484. № 2. С. 209-214. DOI: $10.31857 /$ S0869-56524842209-214

9. Likhanov I. I., Santosh M. Neoproterozoic intraplate magmatism along the western margin of the Siberian Craton: implications for breakup of the Rodinia supercontinent // Precambrian Research. 2017. Vol. 300. pp. 315-331. DOI: 10.1016/J.PRECAMRES.2017.08.019

10. Лиханов И. И., Ревердатто В. В. Р-Т-t эволюция метаморфизма в Заангарье Енисейского кряжа: петрологические и геодинамические следствия // Геология и Геофизика. 2014. T. 55. № 3. C. 385-416. URL:

https://elibrary.ru/item.asp?id=21975296 (дата обращения 04.02.2020).

11. Лиханов И.И., Ревердатто В.В., Козлов П.С. Коллизионные метаморфические комплексы Енисейского кряжа: особенности эволюции, возрастные рубежи и скорость эксгумации // Геология и Геофизика. 2011. Т. 52. № 10. С. $1593-$ 1611. URL: https://elibrary.ru/item.asp?id=17080083 (дата обращения 04.02.2020).

12. Лиханов И. И., Козлов П. С., Попов Н. В., Ревердатто В. В., Вершинин А. Е. Коллизионный метаморфизм как результат надвигов в заангарской части Енисейского кряжа // Доклады Академии Наук. 2006. Т. 411. № 2. С. 235-239. URL: https://elibrary.ru/item.asp?id=9316975 (дата обращения 04.02.2020).

13. Likhanov I. I., Santosh M. A-type granites in the western margin of the Siberian Craton: implications for breakup of the Precambrian supercontinents Columbia/Nuna and Rodinia // Precambrian Research. 2019. Vol. 328. pp. 128-145. DOI: 10.1016/J.PRECAMRES.2019.04.018

14. Лиханов И. И., Ревердатто В. В., Козлов П. С., Зиновьев С. В., Хиллер В. В. P-T-t реконструкция метаморфической истории Южно-Енисейского кряжа (Сибирский кратон): петрологические следствия и связь с суперконтинентальными циклами // Геология и геофизика. 2015. Т. 56. № 6. С. 1031-1056. DOI: 10.15372/GiG20150601

15. Лиханов И. И., Ревердатто В.В.Геохимия, возраст и особенности петрогенезиса пород гаревского метаморфического комплекса Енисейского кряжа // Геохимия. 2014. Т. 52. № 1. C. 3-25. DOI: 10.7868/S001675251401004X

16. Likhanov I. I., Reverdatto V. V., Kozlov P. S., Khiller V. V., Sukhorukov V. P. P-T-t constraints on polymetamorphic complexes of the Yenisey Ridge, East Siberia: implications for Neoproterozoic paleocontinental reconstructions // Journal of Asian Earth Sciences. 2015. Vol. 113. pp. 391-410. DOI: 10.1016/J.JSEAES.2014.10.026

17. Likhanov I. I. Mass-transfer and differential element mobility in metapelites during multistage metamorphism of Yenisei Ridge, Siberia. In: Ferrero S., Lanari P., Gonsalves P. \& Grosch E. G. (eds) Metamorphic Geology: Microscale to Mountain Belts. Geological Society, London, Special Publications. Vol. 478. pp. 89-115. DOI: 10.1144/SP478.11

18. Likhanov I. I. Chloritoid, staurolite and gedrite of the highalumina hornfelses of the Karatash pluton // International Geo- logy Review. 1988. Vol. 30. no. 8. pp. 868-877. DOI: 10.1080/00206818809466067

19. Лиханов И. И. Минеральные реакции в высокоглиноземистых и железистых роговиках в связи с проблемой устойчивости редких минеральных парагенезисов контактового метаморфизма // Геология и геофизика. 2003. Т. 44. № 4. С. 301-312. URL:

http://www.sibran.ru/journals/120372\&ARTICLE_ID=124548 (дата обращения 04.02.2020).

20. Лиханов И. И., Ревердатто В. В., Селятицкий А. Ю. Минеральные равновесия и Р-Т диаграмма для железистоглиноземистых метапелитов в системе KFMASH // Петрология. 2005. Т. 13. № 1. С. 81-92. URL:

https://elibrary.ru/item.asp?id=9140295 (дата обращения 04.02.2020).

21. Likhanov I. I., Reverdatto V. V. Precambrian Fe- and Alrich pelites from the Yenisey Ridge, Siberia: geochemical signatures for protolith origin and evolution during metamorphism // International Geology Review. 2008. Vol. 50. no. 7. pp. 597623. DOI: $10.2747 / 0020-6814.50 .7 .597$

22. Лиханов И. И., Козлов П. С., Полянский О. П., Попов Н. В., Ревердатто В. В., Травин А. В., Вершинин А. Е. Неопротерозойский возраст коллизионного метаморфизма в Заангарье Енисейского кряжа (по ${ }^{40} \mathrm{Ar}-{ }^{39} \mathrm{Ar}$ данным) // Доклады Академии Наук. 2007. Т. 412. № 6. С. 799-803. URL: https://elibrary.ru/item.asp?id=9505868 (дата обращения 04.02.2020).

23. Лиханов И. И., Ревердатто В. В., Вершинин А. Е. Железисто-глиноземистые метапелиты тейской серии Енисейского кряжа: геохимия, природа протолита и особенности поведения вещества при метаморфизме // Геохимия. 2008. Т. 46. № 1. C. 20-41. URL: https://elibrary.ru/item.asp?id=9591026 (дата обращения 04.02.2020).

24. Wu C. M., Zhao G. R. Recalibration of the garnet-muscovite geothermometer and the garnet-muscovite-plagioclase-quartz geobarometer for metapelitic assemblages // Journal of Petrology. 2006. Vol. 47. pp. 2357-2368. DOI: 10.1093/petrology/eg1047

25. Wu C. M., Zhao G. R. The metapelitic garnet-biotitemuscovite-aluminosilicate-quartz (GBMAQ) geobarometer // Lithos. 2007. Vol. 97. pp. 365-372. DOI: 10.1016/j.lithos.2007.01.003

26. Wolfram S. The Mathematica Book. 5th edn. Champaign IL: Wolfram Media Inc. 2003. 544 p. URL:

http://www.wolfram-media.com/mathematicabook.html

27. Likhanov I. I., Polyansky O. P., Reverdatto V. V., Memmi I. Evidence from Fe- and Al-rich metapelites for thrust loading in the Transangarian Region of the Yenisey Ridge, eastern Siberia // Journal of Metamorphic Geology. 2004. Vol. 22. pp. 743-762. DOI: 10.1111/J.1525-1314.2004.00546.X

28. Reverdatto V. V., Likhanov I. I., Polyansky O. P., Sheplev V. S., Kolobov V. Yu. The nature and models of metamorphism. Chum: Springer. 2019. 330 p. DOI: 10.1007/978-3-030-03029-2 29. Лиханов И. И. Метаморфические индикаторы геодинамических обстановок коллизии, растяжения и сдвиговых зон земной коры // Петрология. 2020. Т. 28. № 1. С. 4-22. DOI: $10.31857 /$ S0869590320010045

30. Miyashiro A. Evolution of metamorphic belts // Journal of Petrology. 1961. Vol. 2. pp. 277-311. DOI:

10.1093/petrology/2.3.277 


\title{
The first data on syn-accretionary medium-pressure metamorphism on the western margin of the Siberian Craton (Yenisei Ridge)
}

\author{
(C2020 P. S. Kozlov ${ }^{1}$, I. I. Likhanov ${ }^{2}$, V. V. Khiller ${ }^{1}$ \\ ${ }^{I}$ Zavaritsky Institute of Geology and Geochemistry Zavaritsky, Ural Branch \\ of the Russian Academy of Sciences, 15 Vonsovsky st., Yekaterinburg, 620016 Russian Federation \\ ${ }^{2}$ Sobolev Institute of Geology and Mineralogy Siberian Branch of the Russian Academy of Sciences, \\ 3 Akad. Koptyuga ave., Novosibirsk, 630090, Russian Federation
}

\begin{abstract}
Introduction. The tectonic evolution of the Siberian Cratonic margins offers important clues for global paleogeographic reconstructions, particularly with regard to the complex geological history of Central Asia. The Yenisei Ridge, an ancient fold-and-thrust orogenic on the western margin of the Siberian Craton, forms part of the Central Asian Orogenic Belt (CAOB) and is a key to understand the Precambrian tectonic evolution of the Siberian Craton and crustal growth in the CAOB. Accretionarycollisional processes during the Neoproterozoic history of this region are genetically and spatially associated with the formation of the Paleo-Asian Ocean (PAO). The questions of how Yenisei Ridge terranes are related to the PAO evolution and their subsequent accretion to the Siberian Craton are in many aspects still far from being answered, which raises interest in the features of the development of accretionary-subduction structures in paleoocean-continent transitional zones. The article discusses the genetic relationship of tectonics and metamorphism with accretion-collision processes at the convergent plate boundary at the western margin of the Siberian Craton.

Methodology. The petrological, geochemical and geochronological studies of the garnet-staurolite-kyanite blastomylonites of the Garevka metamorphic complex of the Yenisei Ridge were performed.

Results and discussion. At an early stage (630-610 Ma), metamorphic complexes were formed with a composition close to those of paired metamorphic belts. These complexes were characterized by a conjugate manifestation of the blueschist facies HP/LT metamorphism at $8-10 \mathrm{kbar} / 400-450^{\circ} \mathrm{C}$ and the zonal low-pressure LP/HT metamorphism of the andalusite-sillimanite (low-pressure) type at 3.4-3.6 $\mathrm{kbar} / 435-450^{\circ} \mathrm{C}$. During the subsequent (610-590 Ma) accretion-collision deformation processes, the latter rocks underwent dynamic metamorphism at $6.3-6.6 \mathrm{kbar} / 570-600{ }^{\circ} \mathrm{C}$ with the formation of highpressure tectonites in the suture zone.

Conclusion. The polycyclic development of the processes of formation of these rocks at the convergent boundary of "paleocontinent-paleocean" in the time interval of 630-590 Ma was established.
\end{abstract}

Key words: metamorphism geothermobarometry, in situ U-Th-Pb monazite geochronology, Garevka complex, Siberian Craton

For citation: Kozlov P.S., Likhanov I.I., Khiller V.V. The first data on syn-accretionary medium-pressure metamorphism at the western margin of the Siberian Craton (Yenisei Ridge) // Vestnik Voronezhskogo gosudarstvennogo universiteta. Seriya: Geologiya $=$ Proceedings of Voronezh State University. Series: Geology, 2020, No. 1. P. 78-86. DOI: https://doi.org/10.17308/geology.2020.1/2516

\footnotetext{
${ }^{凶}$ Igor I. Likhanov, E-mail: likh@igm.nsc.ru
} 
Funding: The study was performed according to the research plan of the V.S. Sobolev Institute of Geology and Mineralogy Siberian Branch Russian Academy of Sciences (Novosibirsk), the study was funded by RFBR project (no. 18-05-00152), and by the State Task of Zavaritsky Institute of Geology and Geochemistry of the Ural Branch of the Russian Academy of Sciences (Yekaterinburg; AAAA-A18-118052590032-6).

Conflict of interests: The authors declare the absence of obvious and potential conflicts of interest related to the publication of this article.

\section{REFERENCES}

1. Reverdatto V. V., Likhanov I. I., Polyansky O. P., Sheplev V. S., Kolobov V. Yu. Priroda i modely metamorfizma. [The nature and models of metamorphism]. Novosibirsk, Izd-vo SO RAN, 2017. 331 p. Available at:

https://elibrary.ru/item.asp?id=29167743 (accessed 04.02.2020). (in Russ.)

2. Dobretsov N. L. Evolution of the structures in the Urals, Kazakhstan, Tien Shan, and Altai-Sayan region within the Ural-Mongolian foldbelt (Paleoasian Ocean). Russian Geology and Geophysics, 2003, vol. 44, pp. 3-26. URL: http://sibran.ru/en/journals/issue.php?ID=120367\&ARTICLE_I $\mathrm{D}=122168$

3. Likhanov I. I., Nozhkin A. D., Savko K. A. Accretionary tectonics of rock complexes in the western margin of the Siberian Craton. Geotectonics, 2018, vol. 52, no. 1, pp. 22-44. DOI: 10.1134/S0016852118010107

4. Kozlov P. S., Filippov Yu. F., Likhanov I. I., Nozhkin A. D. Geodynamic model of the Neoproterozoic evolution of the Yenisei paleosubduction zone (western margin of the Siberian Craton), Russia. Geotectonics, 2020, vol. 54, no 1, pp. 54-67. DOI: $10.1134 /$ S0016852120010069

5. Likhanov I. I., Nozhkin A. D., Reverdatto V. V., Kozlov P. S Grenville tectonic events and evolution of the Yenisei Ridge at the western margin of the Siberian craton. Geotectonics, 2014, vol. 48, no. 5, pp. 371-389. DOI: 10.1134/S0016852114050045

6. Likhanov I. I., Savko K. A. First data on the nature and age of the protolith of high-pressure tectonites of Yenisei Ridge: a link to the early stage of formation of the Paleoasian Ocean. Doklady Earth Sciences, 2019, vol. 484, no. 2, pp. 211-216. DOI:10.1134/S1028334X1902023

7. Likhanov I. I., Régnier J.-L., Santosh M. Blueschist facies fault tectonites from the western margin of the Siberian Craton: Implications for subduction and exhumation associated with early stages of the Paleo-Asian Ocean. Lithos, 2018, vol. 304 307, pp. 468-488. DOI: 10.1016/J.LITHOS.2018.02.021

8. Likhanov I. I., Kozlov P. S., Savko K. A., Zinoviev S. V., Krylov A. A. The first petrological evidence for subduction at the western margin of the Siberian Craton. Doklady Earth Sciences, 2019, vol. 484, no. 1, pp. 79-83. DOI: $10.1134 / \mathrm{S} 1028334 \mathrm{X} 19010124$

9. Likhanov I. I., Santosh M. Neoproterozoic intraplate magmatism along the western margin of the Siberian Craton: implications for breakup of the Rodinia supercontinent. Precambrian Research, 2017, vol. 300, pp. 315-331. DOI: 10.1016/J.PRECAMRES.2017.08.019

10. Likhanov I. I., Reverdatto V. V. P-T-t constraints on the metamorphic evolution of the Transangarian Yenisei Ridge: geodynamic and petrological implications. Russian Geology and Geophysics, 2014, vol. 55, pp. 299-322. DOI:

\subsection{6/J.RGG.2014.01.013}

11. Likhanov I. I., Reverdatto V. V., Kozlov P. S. Collisionrelated metamorphic complexes of the Yenisei Ridge: their evolution, ages, and exhumation rate. Russian Geology and Geophysics, 2011, vol. 52, no. 10, pp. 1256-1269. DOI: 10.1016/J.RGG.2011.09.015

12. Likhanov I. I., Kozlov P. S., Popov N. V., Reverdatto V. V., Vershinin A.E. Collision metamorphism as a result of thrusting in the Transangara region of the Yenisei Ridge. Doklady Earth Sciences, 2006, vol. 411, no. 1, pp. 1313-1317. DOI: 10.1134/S1028334X06080332

13. Likhanov I. I., Santosh M. A-type granites in the western margin of the Siberian Craton: implications for breakup of the Precambrian supercontinents Columbia/Nuna and Rodinia. Precambrian Research, 2019, vol. 328, pp. 128-145. DOI: 10.1016/J.PRECAMRES.2019.04.018

14. Likhanov I. I., Reverdatto V. V., Kozlov P. S., Zinoviev S.V., Khiller V.V. P-T-t reconstructions of South Yenisei Ridge metamorphic history (Siberian Craton): petrological consequences and application to supercontinental cycles. Russian Geology and Geophysics, 2015, vol. 56, no. 6, pp. 805-824. DOI: 10.1016/J.RGG.2015.05.001

15. Likhanov I. I., Reverdatto V. V. Geochemistry, age and petrogenesis of rocks from the Garevka metamorphic complex, Yenisey Ridge. Geochemistry International, 2014, vol. 52, no. 1, pp. 1-21. DOI: 10.1134/S0016702914010042

16. Likhanov I. I., Reverdatto V. V., Kozlov P. S., Khiller V. V., Sukhorukov V. P. P-T-t constraints on polymetamorphic complexes of the Yenisey Ridge, East Siberia: implications for Neoproterozoic paleocontinental reconstructions. Journal of Asian Earth Sciences, 2015, vol. 113, pp. 391-410. DOI: 10.1016/J.JSEAES.2014.10.026

17. Likhanov I. I. Mass-transfer and differential element mobility in metapelites during multistage metamorphism of Yenisei Ridge, Siberia. In: Ferrero S., Lanari P., Gonsalves P. \& Grosch E. G. (eds) Metamorphic Geology: Microscale to Mountain Belts. Geological Society, London, Special Publications, vol. 478, pp. 89-115. DOI: $10.1144 /$ SP478.11

18. Likhanov I. I. Chloritoid, staurolite and gedrite of the highalumina hornfelses of the Karatash pluton. International Geology Review, 1988, vol. 30, no. 8, pp. 868-877. DOI: $10.1080 / 00206818809466067$

19. Likhanov I. I. Mineral reactions in high-alumina ferriferous metapelitic hornfelses in connection with the problem of stability of rare parageneses of contact metamorphism. Geologiya $i$ Geofizika. 2003. vol. 44, no. 4. pp. 305-316. URL: http://sibran.ru/en/journals/ID=120372\&ARTICLE_ID=124548 20. Likhanov I. I., Reverdatto V. V., Selyatizkii A. Y. Mineral equilibria and $\mathrm{P}-\mathrm{T}$ diagram for $\mathrm{Fe}$ - and $\mathrm{Al}$-rich metapelites in the KFMASH system $\left(\mathrm{K}_{2} \mathrm{O}-\mathrm{FeO}-\mathrm{MgO}-\mathrm{Al}_{2} \mathrm{O}_{3}-\mathrm{SiO}_{2}-\mathrm{H}_{2} \mathrm{O}\right)$. Petrology, 2005, vol. 13, no. 1, pp. 73-83. URL: https://elibrary.ru/item.asp?id=9140295

21. Likhanov I. I., Reverdatto V. V. Precambrian Fe- and Alrich pelites from the Yenisey Ridge, Siberia: geochemical signatures for protolith origin and evolution during metamorphism. International Geology Review, 2008, vol. 50, no. 7, pp. 597623. DOI: $10.2747 / 0020-6814.50 .7 .597$

22. Likhanov I. I., Kozlov P. S., Polyansky O. P., Popov N. V., Reverdatto V. V., Travin A. V., Verschinin A. E. Neoproterozoic age of collisional metamorphism in the Transangarian Yenisey Ridge:based on ${ }^{40} \mathrm{Ar}-{ }^{39} \mathrm{Ar}$ data. Doklady Earth Sciences, 2007, vol. 413, pp. 234-237. DOI: 10.1134/S1028334X07020225

23. Likhanov I. I., Reverdatto V. V., Verschinin A. E. Fe- and Al-rich metapelites of the Teya sequence, Yenisei Range: geochemistry, protoliths and the behavior of their matter during 
metamorphism. Geochemistry International, 2008, vol. 46, no. 1, pp. 17-36. DOI: 10.1007/S11476-008-1002-1

24. Wu C. M., Zhao G. R. Recalibration of the garnet-muscovite geothermometer and the garnet-muscovite-plagioclase-quartz geobarometer for metapelitic assemblages. Journal of Petrology, 2006, vol. 47, pp. 2357-2368. DOI: 10.1093/petrology/egl047

25. Wu C. M., Zhao G. R. The metapelitic garnet-biotitemuscovite-aluminosilicate-quartz (GBMAQ) geobarometer. Lithos, 2007, vol. 97, pp. 365-372. DOI: 10.1016/j.lithos.2007.01.003

26. Wolfram S. The Mathematica Book. 5th edn. Champaign IL: Wolfram Media Inc. 2003, 544 p. URL: http://www.wolfram-media.com/mathematicabook.html 27. Likhanov I. I., Polyansky O. P., Reverdatto V. V., Memmi I.
Evidence from Fe- and Al-rich metapelites for thrust loading in the Transangarian Region of the Yenisey Ridge, eastern Siberia. Journal of Metamorphic Geology, 2004, vol. 22, pp. 743-762. DOI: $10.1111 / \mathrm{J} .1525-1314.2004 .00546 . X$

28. Reverdatto V. V., Likhanov I. I., Polyansky O. P., Sheplev V. S., Kolobov V. Yu. The nature and models of metamorphism. Chum: Springer. 2019, 330 p. DOI: 10.1007/978-3-030-03029-2 29. Likhanov I. I. Metamorphic indicators for collision, extension and shear zones geodynamic settings of the Earth's crust. Petrology. 2020. vol. 28. no. 1. pp. 1-16. DOI: 10.1134/S086959112001004X

30. Miyashiro A. Evolution of metamorphic belts. Journal of Petrology, 1961, vol. 2, pp. 277-311. DOI:

10.1093/petrology/2.3.277
Козлов Павел Сергеевич - к. г.-м. н., старший научный сотрудник, Институт геологии и геохимии им А. Н. Заварицкого, Уральского отделения Российской академии наук, Екатеринбург, Российская Федерация; E-mail: geoeco2012@ yandex.ru; ORCID https://orcid.org/0000-0001-5886-7908

Лиханов Игорь Иванович - д. г.-м. н., ведущий научный сотрудник, Институт геологии и минералогии им. В. С. Соболева Сибирского отделения Российской Академии наук, Новосибирск, Российская Федерация; E-mail: likh@igm.nsc.ru; ORCID https://orcid.org/0000-0003-4422-1676

Хиллер Вера Витальевна - к. г.-м. н., старший научный сотрудник, Институт геологии и геохимии им А. Н. Заварицкого, Уральского отделения Российской академии наук, Екатеринбург, Российская Федерация; E-mail:hilvervit@mail.ru; ORCID https://orcid.org/0000-0001-8491-4958

Все авторы прочитали и одобрили окончательный вариант рукописи.
Pavel S. Kozlov - PhD in Geol.-Min., senior researcher, Institute of Geology and Geochemistry, RAS Ural Branch, Yekaterinburg, Russian Federation; E-mail: geoeco2012@yandex.ru; ORCID https://orcid.org/0000-0001-5886-7908

Igor I. Likhanov - PhD, Dr. habil. in Geol.-Min., principal research fellow, Sobolev Institute of Geology and Mineralogy of Siberian Branch, Russian Academy of Sciences, Novosibirsk, Russian Federation; E-mail: likh@igm.nsc.ru; ORCID https://orcid.org/0000-0003-4422-1676

Vera V. Khiller - PhD in Geol.-Min., senior researcher, Institute of Geology and Geochemistry, RAS Ural Branch, Yekaterinburg, Russian Federation; E-mail: hilvervit@mail.ru; ORCID https://orcid.org/0000-0001-8491-4958

All authors have read and approved the final manuscript. 